do not detract from its great value. It is an authoritative, readable, and informative account of the anomalies of the human chromosome and of their clinical results.

P. E. Polani

Die Chromosomenstruktur des Menschen in Mitosis und Meiosis. By Paul Eberle. (Pp. xii + 261; 113 figures. DM 58.) Stuttgart: Gustav Fischer Verlag. 1966.

This monograph, the second in a series on evolution by the Fischer Verlag, deals with evolutionary changes only in some comparative and theoretical sections. The text is mainly devoted to a clear and detailed description of the mitotic and male-meiotic structures of human and rodent (mouse, rat, hamster) chromosomes, and to the chromosomes of two insect species (Drosophila hydei and Locusta migratoria) and of a dioecious plant (Melandrium) -descriptions based mostly on the author's own studies and lavishly illustrated by his own photographs. As such it presents an excellent introduction into normal animal cytology, but it does not describe very fully the chromosomal aberrations of man.

An original feature of the book is a discussion in the last chapter on the role of chromosomal aberrations and of mutations and other related changes in anthropoid speciation. These are also speculations on the future chromosomal development of our species. These are illustrated by a series of hypothetical karyograms, showing a gradual reduction from the normal diploid number of 46 to 44,42 and 40 .

Separate bibliographies are arranged after the individual sections and there are additional references at the end of the book. There is no index, but there is a fairly detailed list of contents at the beginning of the book.

\section{H. KaLmUS}

The Role of Chromosomes in Development. 23rd Symposium of the Society for the Study of Development and Growth. Edited by Michael Locke. (Pp. xii + 290; illustrated. \$11.00.) New York; London: Academic Press. 1964.

The contents of this book, which are papers read at the 23rd Symposium of the Society for the Study of Development and Growth, are not closely related to the title. The introductory chapter, which has the same title as the book, reviews the problems and is perhaps suitably speculative but even here most of the discussion is of basic molecular and cell metabolism mechanisms. Of the remaining chapters only that on genetic and functional mosaicism in the mouse, and that on genetic control and regulation of developmental pathways, are of a kind which the title of the book suggests.

The other chapters by distinguished authors are interesting and any elucidation of gene action and control of cellular differentiation in either the simplest or the most complex of organisms will lead to a better understanding of the developmental process. Further, the corpus of knowledge based on experimental findings in this field is so enormous that reviews by authorities are always welcome. There are, however, so many closely argued published papers of these types that no one can be expected to read and absorb them all. This volume was published in 1964 and the papers were presented earlier that year. In such circumstances the non-expert reader must wonder what is now out of date and what is still valid.

This is a well-produced and clearly illustrated book and all the subjects dealt with are well reviewed. These are, in addition to those already mentioned, structural patterns and the functional organization of chromosomes; chromosomal proteins (a most useful introduction); binding of actinomycin as a model for the complexforming capacity of DNA; DNA replication sequences in higher animals; localized DNA synthesis in polytene chromosomes and its implications; chromosomal RNA and other nuclear RNA fractions; genetic repression of $\mathrm{R}$ action in maize; and macronuclear differentiation and subnuclear assortment in ciliates.

Clare Davison

The Chromosomes of the Algae. Edited by Maud B. E. Godward. (Pp. ix +212 ; illustrated. 55s.) London: Edward Arnold. 1966.

This little book consists of a number of articles by various authors, each describing his or her own interest. The editor and author of an account of the green algae is Professor Maud Godward. The authors have been left to their own devices without interference from the editor, excepting, one assumes, a general directive as to form and content. The result is a description of the techniques used and observations made on the nuclear cytology of six of the major groups of algae. Four groups have been omitted for lack of extensive information about their chromosomes and one is only briefly mentioned. The layout of all the chapters follows a common pattern, so it is easy to make comparisons from one group to another, should one wish to do so. In every case the techniques have been described with great clarity so it should be possible for anyone wishing to do similar work to achieve comparable results. The main virtue of the book is the almost casual way in which the cytological virtuosity present in the algae is displayed. Some of the groups described are fairly humdrum, and they offer nothing that cannot be seen better in angiosperms. One or two groups, however, have built a whole way of life on what might be described as an unusual cytology. The information given can only stimulate curiosity and a number of questions. For example, the meiotic problems posed by crossing-over in chromosomes with diffuse centromeres, the equational segregation at the first meiotic division in Spirogyra, the regulation of chromosome number and size in organisms where, because of diffused centromeres, chromosomes can fragment indefinitely and still segregate properly are all teasers. One must also mention the article by Dixon on the red algae. This is a scholarly treatment of a group of algae, which has apparently eluded or deluded the body of descriptive botanists and remained 
until very recently a taxonomical and ontogenetic mess. It seems that their chromosomes are now giving them away.

It would be easy to find fault with this book, but wrong to discourage authors from writing the kind of detailed descriptive accounts now thought to belong to the botany of another age. They are, after all, the foundation of experimental science. It might, however, have improved the value of the book as a textbook if there had been, for the benefit of non-algologists, a brief introduction on the classification of the algae with some account of the life cycles. One could also wish that the editor had been less modest and expanded her short introduction into a discussion of the cytology of the algae as a whole.

B. S. Cox

Malignant Transformation by Viruses. Edited by W. H. Kirsten. (Pp. xiv +177; 39 figures. DM 32. Berlin, Heidelberg, New York: Springer-Verlag. 1966.

This is the 6th volume in this publisher's new series 'Recent Results in Cancer Research', and is the report of a teaching symposium held at the University of Chicago in February 1966. The meeting was planned to deal with three aspects of the subject: (a) characteristics of malignant transformation, (b) genetics and immunology of malignant transformation, and (c) its significance in relation to human neoplasms. The topics, then, are the now familiar ones: cell transformation by Rous sarcoma virus (Macpherson; Temin); polyoma (Dawe et al.); mammary tumour virus (Lasfargues; De Ome); virus-specified antigens (Habel; Defendi); hybrid adeno-SV40 viruses (Rapp; Black and Igel); cytological effects (Moorhead et al.; Yerganian); virus and human neoplasms (Melnick; Girardi and Jensen; Rabson) and immunological attack (Hilleman)and, as you can see, the names are familiar too! This is a recommendation for the book's authority but also gives warning to those who follow this literature that much of the contents will also be familiar-one paper, in fact, largely summarizes a similar one (by the same author!) in the International fournal of Cancer.

There are two novel features in this book: first, a report (pp. 149-163) of a round-table discussion (Chairman, Huebner) which dealt with questions from the audience especially on the relation of virus-induced tumour specific antigens to malignancy; and second, a summary of the symposium (pp. 164-177) by Sabin. Those unfamiliar with the concepts would do well to begin at this end of the book and then to read the chapters to which his very lucid comments refer. The aim of all this research, with so many different viruses and animals, is, of course, to get nearer to an answer to the real question of which, if any, cancers in man are caused by viruses. Sabin concludes his summary: 'I sometimes ask myself how long should one continue with the search for a possible viral aetiology in human malignancy in the face of repeated frustrations? The only answer that I can come up with is that as long as there are reasonable questions to ask and reasonable techniques with which to attempt to answer them, so long it is necessary to persist.'

R. J. C. HARRIS

Heritage from Mendel. Edited by R. A. Brink and E. D. Styles. (Pp. xii +455 ; illustrated + tables. $\$ 10.00$ cloth and \$2.95 paper.) Madison, Milwaukee, and London: The University of Wisconsin Press. 1967.

This volume reproduces the papers read at the Mendel Centennial Symposium by the Genetics Society of America in 1965. There were several such commemorative symposia and there have been many similar publications in the past presenting papers by various authors, which review the developments that have emerged from Mendel's basic ideas.

The contributors to this volume well represent those working in all areas of genetics at the present time. Inevitably, many papers examine the present position of the reconciliation between traditional genetic concepts and the new molecular genetics, and they are very readable and thought-provoking. Just as inevitably, some authors have taken the opportunity to review entirely the work of their own groups or departments presenting advances in their subjects as if entirely developed by themselves and by their colleagues.

It is impossible even to mention the authors and contents of the 21 papers presented. Indeed, no one reviewer is competent to consider such diverse theoretical and experimental presentations. However, the readers will be particularly interested in the two papers directly concerned with human genetics. L. L. CavalliSforza writes on human populations, reporting mainly on the work from the Pavia School, and this appears to be the best account available of the scope and direction of the fine population studies being carried out there.

It is difficult to imagine anyone whose views on genetics and medicine are more welcome than those of J. F. Crow, who has such immense knowledge and experience of experimental and theoretical genetics, and who has, in recent years, been so closely associated with human genetics problems. Predictably therefore this chapter is very stimulating. At every stage his commentary on recent advances brings them into relation with experimental genetical findings. He has some wise and eminently sane remarks on genetic counselling and on the genetic consequences of medical advances. It is to be hoped that on some future occasion he will expand his remarks on the 'Contribution of Medicine to Genetics'. It seems to the reviewer that the feed-back of problems identified in medicine and medical genetics has reorientated experimental genetic work to a greater extent than is generally realized or is suggested by Crow's article.

It is difficult to know how far, and to whom to recommend this book. The level of contributions is patchy but many are so excellent that a head of a 